\title{
RAFT polymers for protein recognition
}

\author{
Alan F. Tominey ${ }^{1}$, Julia Liese ${ }^{1}$, Sun $\mathrm{Wei}^{2}$, Klaus Kowski ${ }^{2}$, \\ Thomas Schrader ${ }^{* 2}$ and Arno Kraft ${ }^{* 1}$
}

\section{Full Research Paper}

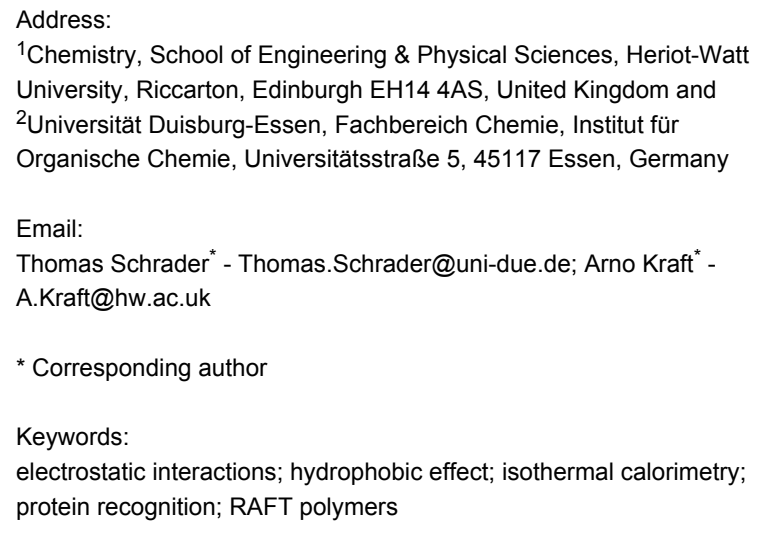

\begin{abstract}
A new family of linear polymers with pronounced affinity for arginine- and lysine-rich proteins has been created. To this end, $\mathrm{N}$-isopropylacrylamide (NIPAM) was copolymerized in water with a binding monomer and a hydrophobic comonomer using a living radical polymerization (RAFT). The resulting copolymers were water-soluble and displayed narrow polydispersities. They formed tight complexes with basic proteins depending on the nature and amount of the binding monomer as well as on the choice of the added hydrophobic comonomer.
\end{abstract}

\section{Introduction}

The ability of biological receptors to bind strongly and specifically to a particular molecular target is an essential part of biological machinery. The best example is the immune system where antibodies are generated in response to minute amounts of foreign antigens. A continual challenge in nanoscale chemistry is to mimic the biological molecular recognition functions by synthetic chemistry with the aim of producing systems of lower complexity. When successful, this will enable the manufacturing of robust and specific synthetic receptors for a given protein target [1]. Proteins are a formidable challenge in this respect because they represent large macromolecules with a characteristic shape, size and highly complex functionalized surface. Artificial protein receptors are desired for protein enrichment and purification, sensing and diagnostics applications, as well as therapeutic uses involving interference with critical protein-protein interactions.

Multivalency represents the key to generate high-affinity materials for biomacromolecules with a sufficient number of binding sites for Coulomb attraction and hydrophobic interactions [2]. A statistical evaluation of crystal structures led to the discovery that hot spots in protein-protein contact areas are 
enriched in aromatic amino acids and in arginine. These are often surrounded by energetically less important residues that most likely serve to occlude bulk solvent from the hot spot and lower the local dielectric constant $[3,4]$.

With this principle in mind, several groups have designed relatively simple linear polymeric structures with branched ionic comonomers and thus achieved remarkable affinities and biological properties. In their elegant work, Kulkarni et al. reported the use of NIPAM-based copolymers for lysozyme recovery by affinity thermoprecipitation. These polymers contained multiple acetamido groups in a hydrophilic environment for maximum interaction with the catalytic cleft and achieved high affinities [5]. Rotello and Thayumanavan have described amphiphilic polymer scaffolds, which nonspecifically bound to chymotrypsin, inhibited its peptidase activity and modulated substrate specificity; very high ionic strengths again released the protein from the polymer $[6,7]$.

Protein recognition by multifunctional polymeric hosts features two prominent advantages. On one hand, it simplifies the complex recognition interface to isolated 1:1 complexes between monomeric binding sites and single complementary amino acid residues, while simultaneously allowing for an extensive induced-fit process of the linear polymer on the protein surface - in other words they encourage polymer/protein self-assembly in order to maximize attractive noncovalent interactions.

A second major advantage of multivalent polymeric hosts is their rapid and efficient synthesis at low cost as well as the high proteolytic stabilities of most polymer backbones. They also pose fewer racemization problems which often accompany proteinogenic amino acids in peptidic environments.

In recent years, our group has developed water-soluble linear polymeric protein binders which contained one or more different binding monomers and displayed micromolar protein affinities [8], accompanied in a number of cases with promising protein selectivities [9]. These linear polymers were all prepared by free radical copolymerization in DMF followed by deprotection of the binding monomers in polymer-analogous transformations. Thus, a polymerized bisphosphonate tetramethyl ester was subjected to LiBr-assisted nucleophilic cleavage to furnish the free bisphosphonate dianion binding site. This procedure has two major drawbacks. First, if the functional groups on the polymer backbone become restricted in their accessability, the final deprotection step will suffer from low conversion rates. Second, the resulting material is polydisperse, rendering the characterization of the protein binding event problematic. Even with incorporated fluorescence labels, the overall emission intensity change resulting from protein addition will reflect only a virtual averaged value, because short and long chains will bind simultaneously, most likely with different affinities and stoichiometries. A quantitative description must inherently suffer from this averaging effect.

\section{Results and Discussion}

Reversible addition-fragmentation chain transfer (RAFT) polymerization [10] and atom-transfer radical polymerization (ATRP) have become extremely useful tools for the controlled synthesis of a wide range of polymers and could solve both problems by formation of monodisperse functionalized polymer chains of equal length, without the need for final polymeranalogous deprotection. So far, there have been no reports of the successful use of ATRP with acrylamides. In contrast, RAFT can be used in a variety of solvents and, most importantly, it is compatible with NIPAM $[11,12]$. For this reason, RAFT was chosen in this paper as the preferred method for controlled synthesis of linear polymers.

For initial screenings we selected a combination of anionic and hydrophobic binding monomers (Figure 1) that were well suited for simultaneous recognition of basic amino acids (Lys/Arg) as well as nonpolar residues (Val, Leu, Ile, Phe). NIPAM was chosen as the main comonomer because it forms polymers which are water-soluble at room temperature and even allow thermoprecipitation with a bound protein guest. NIPAM-based polymers are also reminiscent of peptides since both contain an amide group in the repeat unit. RAFT makes use of a chain transfer agent (CTA) for which we selected the water-soluble trithiocarbonate $\mathbf{8}[13,14]$ which efficiently caps the growing polymer chain, but can be completely removed from the final polymer by reaction with an excess of AIBN and selective polymer precipitation into hexane [11].

Three anionic comonomers suitable for binding lysine and arginine were chosen from earlier work with linear polymers and microgels $[9,15,16]$ : Sodium methacrylate (2) (S), polymerizable tetrazolate $3(\mathrm{~T})$ and bisphosphonate $4(\mathrm{~B})$. These anionic comonomers were directly copolymerized with NIPAM and a hydrophobic acrylamide. The latter carried cyclohexyl $(\mathrm{CH})$, benzyl $(\mathrm{BN})$ or octyl (OC) moieties as hydrophobic residues. In the polymer designation code, the first letter indicates the anionic comonomer used ( $\mathrm{S}, \mathrm{T}$ or $\mathrm{B})$, the subsequent number its mol \% in the monomer mixture; the two-letter abbreviation $(\mathrm{CH}, \mathrm{BN}$ or $\mathrm{OC})$ stands for the hydrophobic comonomer used, again followed by the mol \%; the balance to $100 \mathrm{~mol} \%$ was made up by NIPAM. For example, S10CH10 means that this RAFT copolymer was made from sodium methacrylate (10 mol \%), $N$-cyclohexylacrylamide (10 mol \%), and NIPAM (80 mol \%). 
<smiles>C=CC(=O)NC(C)C</smiles>

1 (NIPAM)<smiles>C=CC(=O)NC1CCCC1</smiles>
5<smiles>C=C(C)C(=O)[O-]</smiles>

2<smiles>C=C(C)C(=O)Nc1nnnn1[NH3+]</smiles>

3

(T)<smiles>C=CC(=O)NCc1ccccc1</smiles>

6

$(\mathrm{BN})$<smiles>C=CC(=O)NCCCCCCC</smiles>

(OC)<smiles>C=C(C)C(=O)Nc1cc(CP(=O)([18O])O[18F])cc(CP(=O)(OC)OC)c1</smiles><smiles>CC(C)(SC(=S)SC(C)(C)C(=O)O)C(=O)O</smiles>

8

Figure 1: Structures of monomers 1-7 and chain transfer agent 8 used in the RAFT polymerizations

RAFT polymerizations were carried out in methanol at $60{ }^{\circ} \mathrm{C}$ for 48 hours in the presence of CTA 8 and azo initiator V-50. The monomer concentration was $0.75 \mathrm{M}$, the molar ratio of $[\mathrm{V}-50] /[\mathrm{CTA}]$ was 3 , and the concentration of CTA and V-50 were adjusted to target polymers with a molecular weight of 3000,7000 or $17000 \mathrm{~g} \mathrm{~mol}^{-1}$ at full conversion. This is possible since the degree of polymerization under RAFT conditions is equal to the ratio between monomer and chain transfer reagent concentration. Conversion was almost $100 \%$, and copolymers were isolated by precipitation in hexane. The absence of low-molecular weight impurities such as monomers was ascertained by ${ }^{1} \mathrm{H}$ NMR spectroscopy. Molecular weights were determined by gel-permeation chromatography (GPC) analysis of the copolymers. Narrow polydispersities $(\leq 1.3)$ were observed for the shorter copolymers, although the highest molecular weights (targeted at $17000 \mathrm{~g} \mathrm{~mol}^{-1}$ ) reached only experimental values of 11,000-12,000 $\mathrm{g} \mathrm{mol}^{-1}$ and also produced slightly higher polydispersities (1.56). For comparison, some copolymers such as S20CH15 were also prepared with a molecular weight of $\sim 3000 \mathrm{~g} \mathrm{~mol}^{-1}$.

Titrations were first carried out by UV-vis spectroscopy with cytochrome $\mathrm{C}$, a protein carrying a chromophore. Second derivative spectra were calculated using the Savitzky-Golay algorithm [17-19]. The second derivative is a useful method of refining the spectra to reveal subtle changes in the UV-vis absorption plot. The UV titration of a typical RAFT copolymer into a solution of cytochrome $\mathrm{C}$ in a phosphate buffer $(\mathrm{pH} 7$, $0.15 \mathrm{M} \mathrm{KCl}$ ) showed characteristic second derivative spectra, similar to those observed in the titrations of microgels into protein solutions [16]. Isosbestic points are clearly visible along with a bathochromic shift of the absorbance peak (Figure 2a). A dissociation constant of $1.6 \times 10^{3} \mathrm{M}^{-1}$ could be fitted to the binding isotherm when the second derivative values of the protein at $415 \mathrm{~nm}$ were plotted against the RAFT polymer concentration (Figure 2b). Cytochrome $\mathrm{C}$ already showed noticable and selective binding to microgels [16] containing 10 mol \% sodium methacrylate and RAFT copolymers of similar composition. Unlike microgels whose molecular weight is very high (typically $10^{6}-10^{8} \mathrm{~g} \mathrm{~mol}^{-1}$ ), cytochrome $\mathrm{C}$ possesses a relatively small molecular weight similar to the RAFT copolymers. As a result, the RAFT copolymers and cytochrome $\mathrm{C}$ favor 1:1 binding. The incorporation of a hydrophobic comonomer further improved binding. The maximum binding strength was observed for polymers containing $15 \mathrm{~mol} \%$ of $\mathrm{N}$-cyclohexylacrylamide and $20 \mathrm{~mol} \%$ of sodium methacrylate (Table 1).

For an independent comparison, the same protein-polymer pairs were subsequently subjected to microcalorimetric titrations (Figure 3), which confirmed the major trends gained from spec-

\begin{tabular}{|c|c|c|}
\hline RAFT Copolymera & $\begin{array}{c}\text { Macroscopic } \\
K_{\mathrm{a}} / \mathrm{M}^{-1}\end{array}$ & $\begin{array}{l}\text { Polymer : Protein } \\
\text { Stoichiometry }\end{array}$ \\
\hline S10CH10 & 400 & $1: 1$ \\
\hline S10BN10 & n.d. & n.d. \\
\hline S100C10 & 20 & $1: 1$ \\
\hline S10CH15 & 1600 & $1: 1$ \\
\hline S20CH15 & $>2000$ & n.d. \\
\hline
\end{tabular}

as = sodium methacrylate, $\mathrm{CH}=\mathrm{N}$-cyclohexylacrylamide, $\mathrm{BN}=$ $\mathrm{N}$-benzylacrylamide, $\mathrm{OC}=\mathrm{N}$-octylacrylamide. 
a)

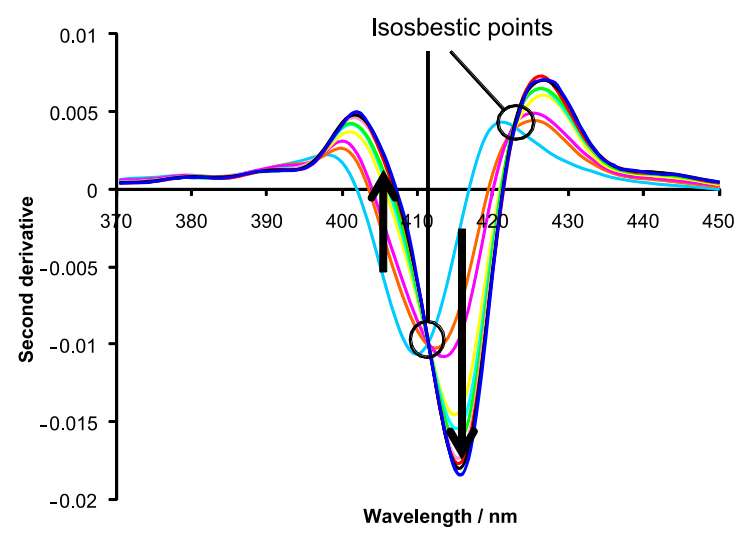

b)

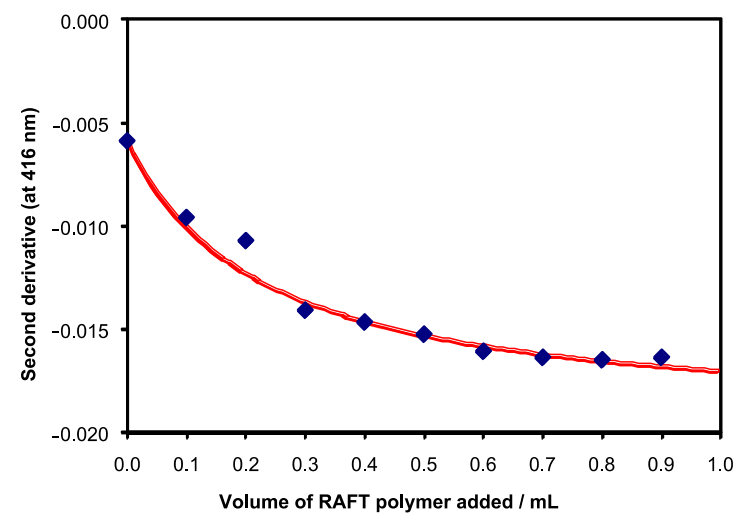

Figure 2: a) Second derivative UV-vis spectra [17-19] observed during a full titration of a stock solution of RAFT copolymer $\mathrm{S} 10 \mathrm{CH} 15$ $\left(6.3 \times 10^{-3} \mathrm{~mol} \mathrm{~L}^{-1}\right)$ into a solution of cyt $\mathrm{C}\left(9.9 \times 10^{-6} \mathrm{~mol} \mathrm{~L}^{-1}\right)$ in phosphate buffer at $\mathrm{pH} 7$ and ionic strength of $0.15 \mathrm{~mol} \mathrm{~L}^{-1} \mathrm{KCl}$. The arrows indicate increasing amounts of RAFT copolymer added. b) Plot of second derivative values at $416 \mathrm{~nm}$ as a function of volume (in $\mathrm{mL}$ ) of RAFT copolymer solution added. The filled diamonds are experimental values, whereas the drawn curve represents the calculated isotherm for a $K_{\mathrm{a}}$ of $1.6 \times 10^{3} \mathrm{M}^{-1}$ assuming $1: 1$ binding [20].

troscopic detection but differed in several details (Table 2). Specifically, RAFT copolymers S10CH10, S10BN10, S10OC10, S10CH15 and S20CH15 were examined in their complex formation with cytochrome C (MW $14 \mathrm{kD}, \mathrm{pI} 9.2)$ and hemoglobin (MW 68 kD, pI 7.0). Negligible heat changes were observed for all titrations with sodium methacrylate-containing polymers, consistent with the small $K_{\mathrm{a}}$ values already determined by UV-vis titrations $\left(20-1600 \mathrm{M}^{-1}\right)$; obviously, the methacrylate anion is a weak binder for lysines and arginines on these protein surfaces. Moderate binding $\left(3 \times 10^{4} \mathrm{M}^{-1}\right)$ was only detected with $\mathrm{S} 20 \mathrm{CH} 15$, which carries twice the amount of carboxylate groups. Association constants were initially calculated for each 1:1 complexation event of a single protein by the copolymer [20]. However, even with S20CH15, no binding was detectable with hemoglobin, confirming an interesting cytochrome $\mathrm{C}$ preference of all sodium methacrylate-carrying poly- mers, which also corresponded to previous results with microgels [16].

By contrast, tetrazolate copolymer T20CH15 and bisphosphonate copolymer B20CH15 showed large enthalpy changes and hence much higher $K_{\mathrm{a}}$ values $\left(>10^{6} \mathrm{M}^{-1}\right)$ which were about two orders of magnitude higher than those achieved with sodium methacrylate copolymer S20CH15 $\left(\sim 10^{4} \mathrm{M}^{-1}\right)$. This is not surprising for the bisphosphonate, which carries twice the amount of negative charges. However, the monoanionic tetrazolate anion is very similar in acidity and hydrogen bond pattern to a carboxylate, so that similar affinities would have been expected. Most likely, the difference is explained by interactions with the $\pi$-face of the tetrazolate anion, which are not possible with a carboxylate.

In all cases, protein complexation by RAFT polymers was endothermic, i.e., entropy-driven. Hence, unspecific electrostatic attraction in combination with solvophobic forces contributed the most towards protein binding.

To quantify the contribution of nonpolar comonomers, hemoglobin was also titrated with pure tetrazolate and bisphosphonate copolymers. Intriguingly, $K_{\mathrm{a}}$ values dropped substantially by $1-2$ orders of magnitude (see Table 1: T20 vs $\mathrm{T} 20 \mathrm{CH} 15)$. In other words, the random incorporation of cyclohexyl comonomers into the polymer was beneficial for the protein recognition event. Close inspection of thermodynamic data revealed that the entropy term was responsible for this increased affinity. We therefore tentatively explain the gain in free energy by an increased classical hydrophobic effect due to the presence of additional nonpolar cyclohexyl residues throughout the polymer chain.

For biological applications, it is desirable to keep the polymer size close to the size of the protein, so that specific 1:1 complexation is favored (Figure 4). In order to investigate this assumption, the sodium methacrylate polymer S20CH15 was titrated as a short oligomer (MW $3000 \mathrm{~g} \mathrm{~mol}^{-1}$ ) and an averagesize polymer (MW $12000 \mathrm{~g} \mathrm{~mol}^{-1}$ ). Direct comparison produced a drastic difference: No binding could be detected for the short version, indicating that size matters and promotes multivalent or cooperative binding.

Finally, the protein series was extended to lysine-rich histone (pI 10), lysozyme (pI 9), proteinase K (pI 8) and bovine serum albumin or BSA (pI 6). Again, the strong binders B20CH15 and T20CH15 were examined concerning their affinities towards proteins of varying $\mathrm{pI}$ (Table 2). In direct comparison, the bisphosphonate seems to be superior to the tetrazolate. While B20CH15 stayed well below micromolar $K_{\mathrm{d}}$ values even with 
a)

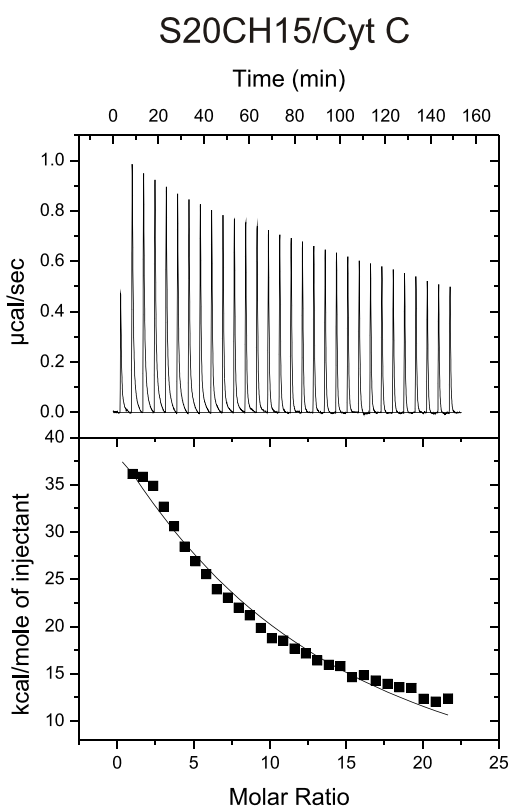

T20CH15/BSA

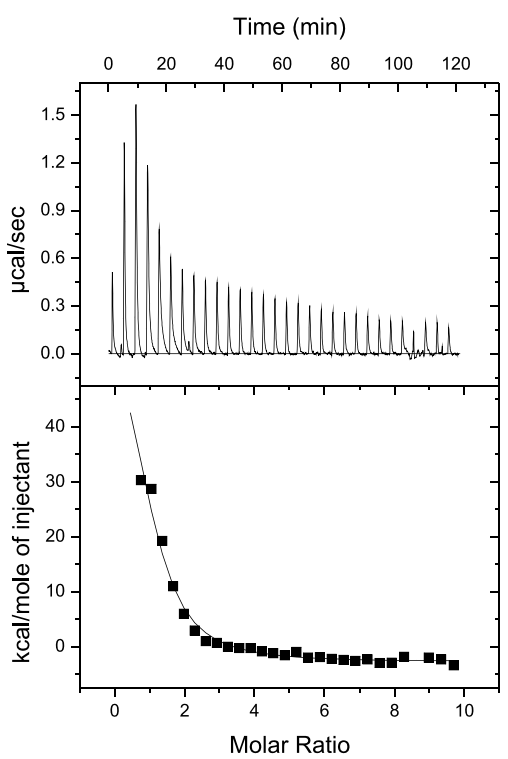

B20CH15/Histone

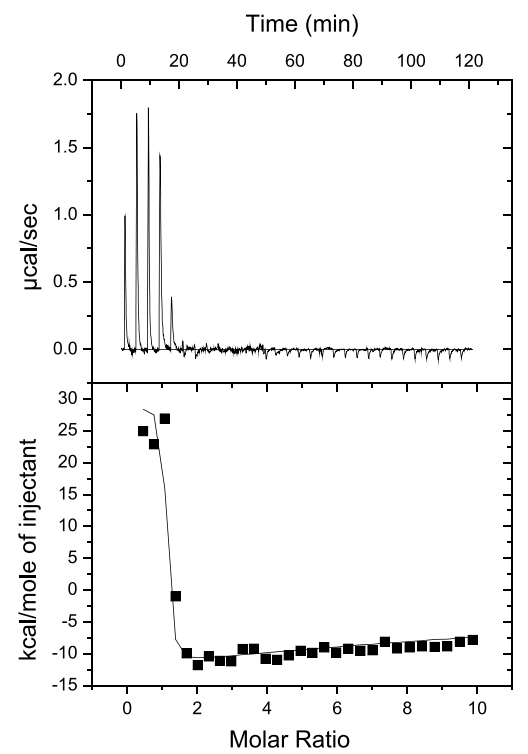

b)

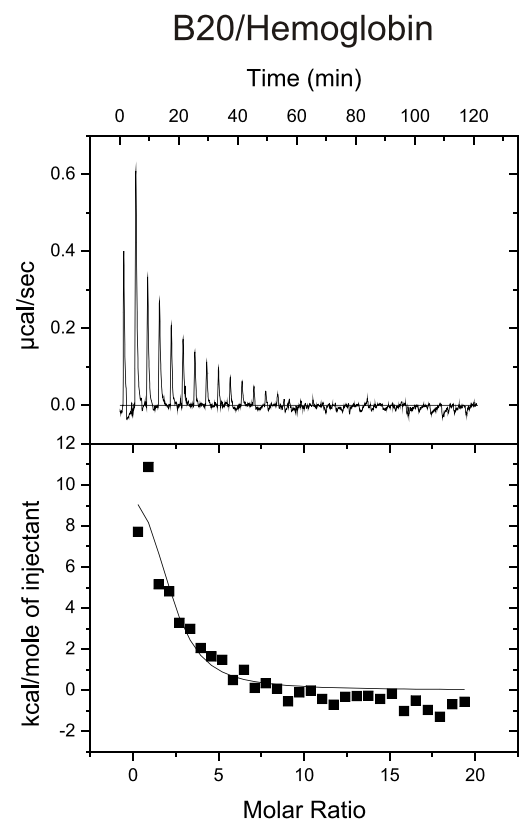

B20CH15/Hemoglobin

Time (min)

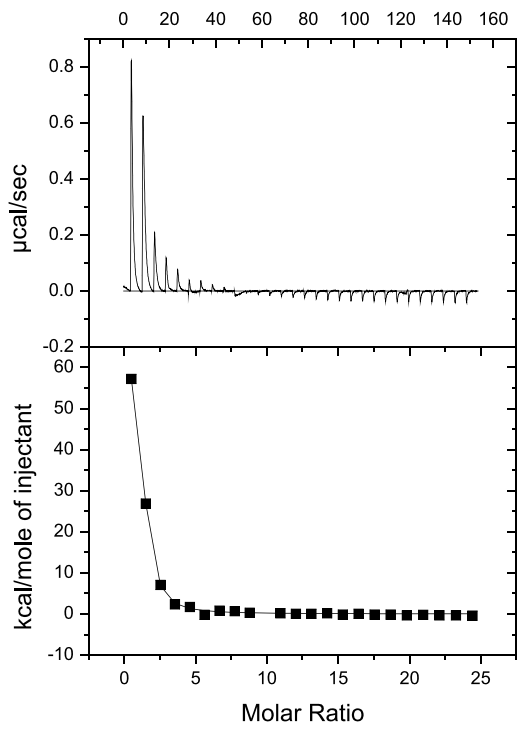

Figure 3: Isothermal calorimetric binding curves for selected polymer/protein host-guest pairs. a) Typical binding curves with representative proteins for the major polymers based on the three anionic binding sites. Note the marked affinity increase from sodium methacrylate over tetrazolate to bisphosphonate dianion. b) Binding curves of two bisphosphonate RAFT copolymers, one without and one with the hydrophobic $N$-cyclohexylacrylamide comonomer $(15 \mathrm{~mol} \%)$. The contribution of the nonpolar cyclohexyl monomer towards hemoglobin binding is evident from the steeper slope of the binding curve.

BSA, T20CH15 hardly ever reached the micromolar regime. Obviously, the bisphosphonate's high negative charge density is especially effective for protein surfaces with a high density of basic amino acids such as the DNA-binding histones or for those offering distinct clusters of cationic amino acid residues (e.g. BSA). Interestingly, although in most cases nonlinear regression converges with an assumed 1:1 complex stoi- chiometry, curve fitting is greatly improved with a sequential binding or 2-sites model [21]. In all these cases, the first polymer binds very tightly to the protein surface, but leaves significant room for a second polymer forming an - admittedly much weaker - 2:1 complex. Histone association with B20CH15 is an illustrative example. The first $K_{\mathrm{d}}$ value is $16 \mathrm{nM}$, followed by very weak binding at a second site with a 
Table 2: Microcalorimetric protein titrations with RAFT polymers

\begin{tabular}{|c|c|c|c|c|c|c|c|c|}
\hline $\begin{array}{c}\text { RAFT } \\
\text { copolymera }\end{array}$ & Protein $^{b}$ & Macroscopic $K_{\mathrm{a}} / \mathrm{M}^{-1}$ & $\begin{array}{l}\text { Polymer : } \\
\text { protein }\end{array}$ & $\begin{array}{c}K_{\mathrm{a}} \text { per residue / } \\
\mathrm{M}^{-1}\end{array}$ & $\begin{array}{l}\text { Monomer : } \\
\text { protein }\end{array}$ & $\begin{array}{c}\Delta G / \mathrm{kcal} \\
\mathrm{mol}^{-1}\end{array}$ & $\begin{array}{c}\Delta H / \mathrm{kcal} \\
\mathrm{mol}^{-1}\end{array}$ & $\begin{array}{c}T \Delta S / \mathrm{kcal} \\
\mathrm{mol}^{-1}\end{array}$ \\
\hline $\mathrm{S} 10 \mathrm{CH} 10$ & Cyt C & NA & - & - & - & - & - & - \\
\hline S10BN10 & Cyt C & NA & - & - & - & - & - & - \\
\hline $\mathrm{s} 100 \mathrm{C} 10$ & Cyt C & NA & - & - & - & - & - & - \\
\hline S10CH15 & Cyt C & NA & - & - & - & - & - & \\
\hline $\mathrm{S} 10 \mathrm{CH} 10$ & Hem & NA & - & - & - & - & - & - \\
\hline $\mathrm{S} 20 \mathrm{CH} 15^{\mathrm{b}}$ & Cyt C & NA & - & - & - & - & - & - \\
\hline $\mathrm{S} 20 \mathrm{CH} 15^{\mathrm{C}}$ & Cyt C & $3 \times 10^{4}$ & $7: 1$ & $9 \times 10^{2}$ & $15: 1$ & - & - & - \\
\hline $\mathrm{S} 20 \mathrm{CH} 15^{\mathrm{C}}$ & Hem & NA & - & - & - & - & - & - \\
\hline T20 & Hem & $\sim 2 \times 10^{4}$ & - & $\sim 9 \times 10^{3}$ & - & - & - & - \\
\hline \multirow[t]{5}{*}{ T20CH15 } & His & $8 \times 10^{5} \rightarrow 5 \times 10^{3}$ & 2 sites & $2 \times 10^{4}$ & - & - & - & - \\
\hline & Lys & $8 \times 10^{5} \rightarrow 5 \times 10^{3}$ & 2 sites & $1 \times 10^{4}$ & $7: 1$ & -5.5 & +21.2 & +26.7 \\
\hline & Prot $\mathrm{K}$ & $4 \times 10^{5} \rightarrow 3 \times 10^{3}$ & 2 sites & $3 \times 10^{3}$ & $13: 1$ & -4.6 & +17.7 & +22.3 \\
\hline & Hem & $4 \times 10^{6}$ & $3: 1$ & $1 \times 10^{4}$ & $78: 1$ & -5.7 & +4.2 & +9.9 \\
\hline & BSA & $4 \times 10^{5} \rightarrow 3 \times 10^{3}$ & $10: 1$ & $6 \times 10^{3}$ & $6: 1$ & -5.2 & +4.4 & +9.6 \\
\hline B20 & Hem & $7 \times 10^{5}$ & $2: 1$ & $7 \times 10^{4}$ & $20: 1$ & -6.6 & +1.2 & +7.8 \\
\hline \multirow[t]{5}{*}{$\mathrm{B} 20 \mathrm{CH} 15$} & $\mathrm{His}$ & $6 \times 10^{7} \rightarrow 7 \times 10^{2}$ & 2 sites & $2 \times 10^{5}$ & $18: 1$ & -7.4 & +2.4 & +9.8 \\
\hline & Lys & $1 \times 10^{6} \rightarrow 3 \times 10^{3}$ & $2: 1$ & $4 \times 10^{4}$ & $15: 1$ & -6.3 & +0.7 & 7.0 \\
\hline & Prot $\mathrm{K}$ & NA & - & - & - & - & - & - \\
\hline & Hem & $4 \times 10^{6}$ & $1: 1$ & $2 \times 10^{5}$ & $15: 1$ & -7.2 & +5.1 & +12.3 \\
\hline & BSA & $2 \times 10^{6}$ & $3: 1$ & $9 \times 10^{4}$ & $5: 1$ & -6.7 & +15.4 & +22.1 \\
\hline
\end{tabular}

as = sodium methacrylate, $\mathrm{T}=$ tetrazolate $3, \mathrm{~B}=$ bisphosphonate $4, \mathrm{CH}=\mathrm{N}$-cyclohexylacrylamide, $\mathrm{BN}=\mathrm{N}$-benzylacrylamide, $\mathrm{OC}=\mathrm{N}$-octylacrylamide.

${ }^{\mathrm{b}} \mathrm{Cyt} \mathrm{C}=$ cytochrome $\mathrm{C} ; \mathrm{Hem}=$ hemoglobin; His = histone; Lys = lysozyme; Prot $\mathrm{K}=$ proteinase $\mathrm{K} ; \mathrm{BSA}=$ bovine serum albumin

${ }^{\mathrm{C}} \mathrm{MW} \sim 3000 \mathrm{~g} \mathrm{~mol}^{-1}$.

${ }^{\mathrm{d}} \mathrm{MW} \sim 17000 \mathrm{~g} \mathrm{~mol}^{-1}$. NA indicates that no binding constant and thermodynamic data were obtained from microcalorimetry titrations, because heat changes were too small.

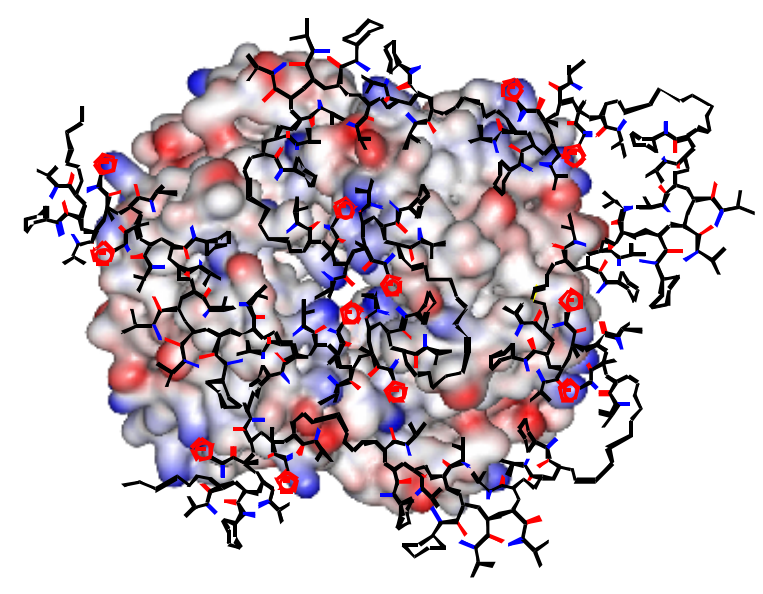

Figure 4: Graphical illustration of the potential binding mode on hemoglobin tetramer (represented as electrostatic potential surface, lysines = blue). The RAFT copolymer T20 CH15 (tetrazole rings = red) undergoes an extensive induced fit procedure on the protein surface maximizing unspecific electrostatic and hydrophobic contacts. Some NIPAM sidechains were omitted for clarity.
$K_{\mathrm{d}}$ of $1 \mathrm{mM}$. With respect to varying pI values, both RAFT polymers display little selectivity: From lysozyme $(\mathrm{pI}>9)$ down to BSA $(\mathrm{pI}<6)$ protein affinities vary by less than one order of magnitude.

\section{Conclusion}

In summary, RAFT copolymerization of NIPAM with monomers containing anionic binding sites for basic amino acids led to polymers of low polydispersities which were effective protein binders in buffered aqueous solution, with tunable stoichiometries close to the ideal 1:1 ratio. Although molecular recognition is based on unspecific electrostatic attraction and hydrophobic forces, those proteins which feature a high density of positive charges on their surfaces are bound especially well by the bisphosphonate site, in some cases reaching micromolar or sub-micromolar $K_{\mathrm{d}}$ values. Copolymerization with $N$-cyclohexylacrylamide introduced additional nonpolar groups beneficial for protein binding, leading to a substantial entropy gain and significantly improving protein affinities. The best pair was a bisphosphonate-containing RAFT copolymer and lysine-rich histone $\left(K_{\mathrm{d}}=16 \mathrm{nM}\right)$. In the future, we intend 
to investigate if it is possible to interrupt the nucleosome complex formation by noncovalent detachment of ds-DNA from its "own" histone proteins using histone-binding RAFT copolymers.

\section{Supporting Information}

\section{Supporting Information File 1}

Full experimental procedures, characterization details, microcalorimetry measurements, UV titration procedures and potentiometric titrations.

[http://www.beilstein-journals.org/bjoc/content/ supplementary/1860-5397-6-66-S1.pdf]

\section{Acknowledgements}

We gratefully thank the School of Engineering and Physical Sciences at Heriot-Watt University for support and Dr Steven Rimmer (Sheffield University) for help with the aqueous GPC of the RAFT copolymers.

\section{References}

1. Schrader, T.; Hamilton, A., Eds. Functional Synthetic Receptors; Wiley-VCH: Weinheim, Germany, 2005.

2. Peczuh, M. W.; Hamilton, A. D. Chem. Rev. 2000, 100, 2479-2494. doi:10.1021/cr9900026

3. Bogan, A. A.; Thorn, K. S. J. Mol. Biol. 1998, 280, 1-9. doi:10.1006/jmbi.1998.1843

4. Larsen, T. A.; Olsen, A. J.; Goodsell, D. S. Structure 1998, 6, 421. doi:10.1016/S0969-2126(98)00044-6

5. Vaidya, A. A.; Lele, B. S.; Deshmukh, M. V.; Kulkarni, M. G. Chem. Eng. Sci. 2001, 56, 5681-5692. doi:10.1016/S0009-2509(01)00169-5

6. Sandanaraj, B. S.; Vutukuri, D. R.; Simard, J. M.; Klaikherd, A.; Hong, R.; Rotello, V. M.; Thayumanavan, S. J. Am. Chem. Soc. 2005, 127, 10693-10698. doi:10.1021/ja051947+

7. Sandanaraj, B. S.; Demont, R.; Aathimanikandan, S. V.; Savariar, E. N.; Thayumanavan, S. J. Am. Chem. Soc. 2006, 128, 10686-10687. doi:10.1021/ja063544v

8. Renner, C.; Piehler, J.; Schrader, T. J. Am. Chem. Soc. 2006, 128, 620-628. doi:10.1021/ja0560229

9. Koch, S.; Renner, C.; Xie, X.; Schrader, T. Angew. Chem., Int. Ed. 2006, 45, 6352-6355. doi:10.1002/anie.200601161

10. Barner-Kowollik, C.; Buback, M.; Charleux, B.; Coote, M. L.; Drache, M.; Fukuda, T.; Goto, A.; Klumperman, B.; Lowe, A. B.; McLeary, J. B.; Moad, G.; Monteiro, M. J.; Sanderson, R. D.; Tongue, M. P.; Vana, P. J. Polym. Sci., Part A: Polym. Chem. 2006, 44, 5809-5831. doi:10.1002/pola.21589

11. Convertine, A. J.; Lokitz, B. S.; Vasileva, Y.; Myrick, L. J.; Scales, C. W.; Lowe, A. B.; McCormick, C. L. Macromolecules 2006, 39, 1724-1730. doi:10.1021/ma0523419

12. Convertine, A. J.; Ayres, N.; Scales, C. W.; Lowe, A. B.; McCormick, C. L. Biomacromolecules 2004, 5, 1177-1180. doi:10.1021/bm049825h

13. Lai, J.; Filla, D.; Shea, R. Macromolecules 2002, 35, 6754-6756. doi:10.1021/ma020362m
14. Adewuyl, Y.; Carmichael, G. Environ. Sci. Technol. 1987, 21, 170-177. doi:10.1021/es00156a602

15. Tominey, A.; Andrew, D.; Oliphant, L.; Rosair, G. M.; Dupré, J.; Kraft, A. Chem. Commun. 2006, 2492-2494. doi:10.1039/b604393c

16. Tominey, A.; Liese, J.; Ewen, D.; Kraft, A. PMSE Prepr. 2007, 97, 964-965.

17. Savitzky, A.; Golay, M. J. E. Anal. Chem. 1964, 36, 1627-1639. doi:10.1021/ac60214a047

18. Barak, P. Anal. Chem. 1995, 67, 2758-2762. doi:10.1021/ac00113a006

19. de Levie, R. Advanced Excel for Scientific Data Analysis; Oxford University Press: Oxford, U.K., 2004; pp 469-481.

20. Connors, K. A. Binding constants; Wiley: New York, 1987.

21. Stoichiometries in the " 1 set of sites" fitting mode were indicated to be between 1 and 2 . Indeed, curve fitting with only two assumed non-identical sites produced much better results than any other ratio.

\section{License and Terms}

This is an Open Access article under the terms of the Creative Commons Attribution License

(http://creativecommons.org/licenses/by/2.0), which permits unrestricted use, distribution, and reproduction in any medium, provided the original work is properly cited.

The license is subject to the Beilstein Journal of Organic Chemistry terms and conditions:

(http://www.beilstein-journals.org/bjoc)

The definitive version of this article is the electronic one which can be found at: doi:10.3762/bjoc.6.66 